\title{
The Relationship between Learning Motivation and Learning Outcomes of Students Chemistry of Grade XI-MNS in 4 State SHS Pematangsiantar
}

\author{
Hisar Marulitua Manurung*, Suprapto Manurung \\ Program Studi Pendidikan Kimia, FKIP, Universitas HKBP Nommensen Pematangsiantar \\ *Email: hisarmanurung03@gmail.com
}

DOI: https://doi.org/10.33369/pendipa.5.3.466-471

\begin{abstract}
ABSTRAK
This study aimed to determine the relationship between learning motivation and learning outcomes of students chemistry of grade XI-MNS (mathematics and natural science). The research design used was quantitative with a correlation approach. The population of this study was all students of class XI-MNS at state senior high school (SHS) 4 Pematangsiantar as many as 205 students for the 2019/2020 Academic Year. The sampling technique for this research was random sampling, which is a random sampling technique with a total sample of 40 students. The instrument used in the study was a non-test (questionnaire) of 20 questions to measure student learning motivation, but measuring chemistry learning outcomes was taken from the odd semester exam scores. The results showed that the percentage of high motivation was $20 \%$, sufficient motivation was $50 \%$, and low motivation was $30 \%$. Student chemistry learning outcomes with a minimum score with a score of 41 and a maximum value with a score of 63 derived from the semester test scores that have been assessed by the field teacher. The correlation coefficient ( $r$ ) in this study is 0.80 and the value of the coefficient of determination $\left(r^{2}\right)$ amounting to 0.63 which indicates that students' chemistry learning outcomes affect $63 \%$ changes in chemistry learning motivation. This results show that the relationship between learning motivation and learning outcomes of students chemistry of grade XI-MNS is very strong.
\end{abstract}

Keywords: Learning Motivation and Learning Outcomes of Chemistry.

\section{INTRODUCTION}

In the Regulation of the Minister of Education and Culture Number 22 of 2016 concerning Process Standards, it is stated that the process standard is a criterion regarding the implementation of learning in educational units to achieve graduate competency standards (Fatimah, 2016). Education is a very strategic process in educating, so it must be done professionally (Suryanti \& Wijayanti, 2019). To realize education that is beneficial to society and the nation, it is necessary to have the role of educators as educational guardians who can become processors in carrying out learning activities whose activities are centered on students. The implementation of learning can run well if it is done in an interesting, inspirational, fun, challenging, and students are motivated to explore their potential, and develop initiative, creativity, and independence according to their interests and talents in building physical and psychological skills.

In general, education carried out in schools aims to educate, expand knowledge and experience and provide insight into humans. This shows that education is a planned, orderly and continuous process that leads to certain goals. Through good education, students can get various provisions in facing the challenges of the global era. The ability to think critically, creatively, and innovatively is an ability that can be cultivated and developed through good education. The learning process of chemistry in the classroom that is not able to motivate students will not be able to develop the ability to think logically, critically, carefully, creatively, innovatively, and systematically as well as an attitude of confidence and discipline. For this reason, if you want students to be motivated, every chemistry teacher must always generate this motivation by improving the quality of 
learning. Teachers are the most important agents in shaping the new curriculum and bringing about changes in educational practice (Prins et al., 2018). The learning process must be designed in such a way by the teacher so that students are actively involved, mentally and physically in learning chemistry.

Based on the results of research obtained by Mohammad regarding learning motivation, the measurement is based on attention with an average score of 2.90 which is categorized as quite good, this happens because students have difficulty learning science lessons (Taufiq et al., 2018). Indications that were found for this difficulty were difficult science material, lack of teaching ability and teacher knowledge, student learning habits, lack of learning resources and study time, and students' negative attitudes towards learning material.

Based on the research results obtained by Ratna about the description of learning motivation with a percentage level of $47.06 \%$ which belongs to the moderate category (Sitompul et al., 2018). The indications found by researchers for this situation are because students are sometimes independent when studying and doing science assignments, learning science is used by students sometimes in their spare time, student learning time at home is sometimes implemented and arranged, and science lessons are delivered. by the teacher, sometimes it is reviewed by students.

Chemistry is an important field of science and students often have difficulty understanding abstract concepts because the chemistry curriculum consists of many abstract concepts or theories so that it is very difficult for students to understand (Gurses et al., 2015). One of the reasons chemistry is difficult to understand is that chemistry demands to be able to think abstractly in certain study materials such as chemical bonds, atomic structure, and atomic models. As a result of these difficulties can have an impact on student learning outcomes of chemistry to decline and the lack of motivation of students to learn.

Ideal learning outcomes include all psychological domains that have changed as a result of students' experiences and learning processes (Muhibbin, 2004). However, it is very difficult to reveal changes in the behavior of all these domains, especially the realm of students' feelings. This is due to changes in learning outcomes that are intangible. The main key to obtaining a measure of student achievement is knowing the outline of the indicator (an indication of a certain achievement) associated with the type of achievement to be expressed or measured.

Motivation can function as a driving force for learning efforts and the achievement of better learning outcomes (Ratumanan, 2004). Motivation can direct students in learning to achieve their goals or ideals. Motivation can play a role in selecting student actions, what to do and what to put aside. Parents' advice is one of the extrinsic motivations (Rumbewas et al., 2018). Support from someone, especially parents can be a strong impetus for a student to learn (Maulida \& Dhania, 2012). Internal and external factors are very influential on student achievement. One of the factors that have a big influence is the factor of interest and motivation (Sari et al., 2020).

The results obtained are following the results of previous research, that the PBL learning model can improve student learning outcomes (Tarigan \& Manurung, 2015). because it is a learning model that involves students being able to learn knowledge related to these problems as well as having the skills to solve problems (Manurung, 2019).

Departing from the problems experienced by students in chemistry learning, it is felt that learning motivation is necessary for students to find out how much it relates to student learning outcomes. Besides, students also have a strong desire to study independently, from the explanation above, the researcher is interested in conducting a study entitled "The Relationship Between Learning Motivation And Learning Outcomes of Students Chemistry of Grade XIMNS in 4 State Senior High School (SHS) Pematangsiantar".

\section{RESEARCH METHODS}

This research was conducted at state senior high school (SHS) 4 Pematangsiantar in class XIMNS in the odd semester of the Academic Year 2019/2020 from March to May 2020. The research design with the correlation technique is used to determine whether there is a relationship 
and to measure how big the relationship is between two variables. This research was conducted in class XI-MNS at state senior high school (SHS) 4 Pematangsiantar with a population of 205 students and taking a sample of 40 students.

The subjects of this study were students of class XI-MNS whose sampling technique used random sampling. Primary data in this study were obtained from the results of a questionnaire about student learning motivation. While the secondary data in this study is documentation taken using the odd semester test scores of class XI-MNS students in the Academic Year. 2019/2020.

The procedures for the implementation of this research are as follows: Providing a non-test (questionnaire) research instrument of 20 statements to measure student learning motivation, Validating the student questionnaire, Determining the population and research sample, Conducting semester exams conducted by the teacher to obtain student chemistry learning outcomes, Processing data obtained from both learning outcomes and questionnaires, and Analyzing data obtained from research and making a conclusion.

The research data obtained in the form of learning motivation and student learning outcomes of chemistry. The instrument used to measure student learning motivation uses a nontest (questionnaire). Chemistry learning outcomes data were obtained from the semester test scores given by the chemistry subject teacher. The learning motivation questionnaire before being used to obtain data is first tested for validity and reliability test.

The data analysis technique is the most decisive step in a study because data analysis serves to conclude the research results. Data analysis aims to classify data based on variables and types of respondents, tabulate data based on variables from all respondents, present data from each variable under study, answer calculations for problem formulations and calculations to test the hypotheses that have been proposed. Data analysis techniques used include normality test, linearity test, and hypothesis testing.

\section{RESULTS AND DISCUSSION}

The data in this study include the variables of learning motivation and student learning outcomes of chemistry. The following is presented the research data:

\section{Motivation to Learn}

The results of the study of learning motivation on chemistry subjects conducted in class XI-MNS state senior high school (SHS) 4 Pematangsiantar with a sample size of 40 students obtained data that the results of the study were in the form of a questionnaire consisting of 20 statements given to students with an assessment scale using a Linkert scale with a score 1-5. The questionnaire was given consists of two statements, namely 10 positive statements and 10 negative statements. The data on the results of the questionnaire on the learning motivation of class XI-MNS state senior high school (SHS) 4 Pematangsiantar are as follows:

Table 1. Statistical Questionnaire Data on Student Motivation for Class XIMNS in Chemistry Subject at State SHS 4 Pematangsiantar.

\begin{tabular}{ccc}
\hline Number & Statistics & Statistics score \\
\hline 1 & Lowest Value & 56 \\
2 & The Highest & 88 \\
3 & Score & 69,58 \\
4 & Average (X) & 6,90 \\
& Standard & \\
& Deviation $(\partial)$ &
\end{tabular}

From the data in Table 1 above, it is obtained the results of the learning motivation questionnaire that the lowest learning motivation with a score of 56 and the highest learning motivation with a score of 88 , and the average student learning motivation with a score of 69.58. As for the classification of student learning motivation, namely: very high learning motivation, high learning motivation, sufficient 
learning motivation, low learning motivation, and very low learning motivation.

If the presentation of the percentage of the classification of student learning motivation is described in a circle, it will be clear that the highest percentage of learning motivation classification is $20 \%$, learning motivation is sufficient by $50 \%$ and learning motivation is low by $30 \%$. However, the classification of learning motivation is more dominated by sufficient motivation to learn. Based on the data, it can be concluded that class XI-MNS students of State SHS 4 Pematangsiantar have a salty learning motivation classification, namely: high motivation, sufficient motivation, and low motivation.

\section{Learning Outcomes}

Student learning outcomes in this study are the odd semester test scores for the 2019/2020 Academic Year at State SHS 4 Pematangsiantar for class XI-MNS. The test questions used to measure learning outcomes consist of multiplechoice questions and essay questions that have been adjusted to the syllabus. The research data shows that the maximum score obtained by students is 63 and the minimum score is 41 .

Table 2. Student Learning Outcomes Statistics for Class XI-MNS on Chemistry Subjects in State SHS 4 Pematangsiantar.

\begin{tabular}{ccc}
\hline No & Statistics & Statistics Score \\
\hline 1 & Minimum Value & 41 \\
2 & Maximum Value & 63 \\
3 & Average & 53,03 \\
4 & Standard Deviation & 5,964 \\
\hline
\end{tabular}

Based on interviews conducted by researchers with teachers in the field of chemistry studies, the value of the minimum completeness criteria for students is 65 . The minimum completeness criteria value is obtained from a combination of test scores, project scores, and students' quizzes. If the student has received a minimum score of 41 , the student will likely get a minimum completeness criterion score of 65. This situation can occur because the project and quiz scores of all students are 80 , it can be said that all students can achieve the minimum completeness criteria score of 65 .

\section{Prerequisite Testing Normality test}

The data that will be tested for normality in this study are the learning motivation variable and the learning outcome variable using the ChiSquare Test which aims to determine whether the data obtained is normally distributed or not. The data requirements are normally distributed if $\mathrm{L}_{\text {Count }}<\mathrm{L}_{\text {table. }}$ Following are the results of the normality test for the $\mathrm{X}$ variable:

Table 3. Normality Test of Learning Motivation Variables and Learning Outcomes

\begin{tabular}{ccccc}
\hline No & Variable & $\mathbf{L}_{\text {Count }}$ & $\mathbf{L}_{\text {table }}$ & Conclusion \\
\hline 1 & $\mathrm{X}$ & 2,7493 & 11,1 & $\begin{array}{c}\text { Terdistribusi } \\
\text { Normal }\end{array}$ \\
\hline
\end{tabular}

\section{Linearity Test}

The linearity test in this study utilizes the Microsoft Excel 2007 program by looking at the linear term value at the 0.05 significance level. According to (Coakes, n.d.) if $\mathrm{F}_{\text {Count }}<\mathrm{F}_{\text {Table }}$ then it is declared linear, and if $F_{\text {Count }}>F_{\text {Table }}$ then it is not linear.

Table 4. Linearity Test of Learning Motivation Variables and Learning Outcomes

\begin{tabular}{cccc}
\hline Correlation & $\mathbf{F}_{\text {Count }}$ & $\mathbf{F}_{\text {Table }}$ & Explanation \\
\hline $\mathrm{X}$ & 0,4155 & 2,1511 & Linier \\
\hline
\end{tabular}

Based on the results of the linearity test, it was found that the relationship between learning motivation and student learning outcomes of chemistry was linear because $\mathrm{F}_{\text {Count }}<\mathrm{F}_{\text {Table }}$.

\section{Hypothesis testing}

The analysis technique used to test uses simple regression analysis techniques. The results of the hypothesis test state that "There is a Relationship between Learning Motivation and Learning Outcomes of Chemistry Class XI-MNS Students of State SHS 4 Pematangsiantar". The results of hypothesis testing can be used manually simple regression test with the help of Microsoft Excel. The results obtained will be compared with $\mathrm{T}_{\text {table, }}$, if $\mathrm{t} \mathrm{T}_{\text {count }}>\mathrm{T}_{\text {table }}$ then the 
hypothesis is accepted. A summary of the results of the hypothesis can be seen in the following table:

Table 5. Research Hypothesis Test of Variables X dan Y

\begin{tabular}{ccccc}
\hline $\mathbf{r}^{2}$ & $\mathbf{T}_{\text {count }}$ & $\mathbf{T}_{\text {table }}$ & Constant & Koefisien \\
\hline 0,63 & 80,84 & 2,02 & 0,74 & 0,92 \\
\hline
\end{tabular}

Based on Table 5, the regression line equation can be obtained as follows:

$$
\mathrm{Y}=0,74+0,92 \mathrm{X}
$$

The regression equation shows that the regression coefficient is positive at 0.92 , which means that if the value of learning outcomes $(\mathrm{X})$ increases by one unit, chemistry learning motivation (Y) increases by 0.92 .

The coefficient of determination $\left(\mathrm{r}^{2}\right)$ is 0.63 which indicates that the learning outcomes of students' chemistry affect $63 \%$ of changes in the learning motivation of students in Class XIMNS State SHS 4 Pematangsiantar.

The research findings show that the overall picture of student learning motivation is in the sufficient category, meaning that students still need to increase learning motivation so that students realize that motivation is very necessary for learning because students who are motivated in learning can prepare themselves well before and are currently studying such as being diligent in learning. , spend more time studying, diligent and persistent when encountering difficulties in learning.

Based on the results of data processing, the highest percentage of learning motivation is to focus on doing tasks with a percentage of $50 \%$. This shows that the success of students in learning is indicated by a focus on learning either in doing assignments or paying attention to the teacher during the lesson.

According to Long "Motivation refers to the psychological processes that lead us to do certain things", it can be interpreted that motivation refers to a psychological process that encourages students to have a strong motivation to obtain the expected results (Fitria et al., 2016).

Based on the data analysis conducted, shows that there is a positive and significant relationship between learning motivation and learning outcomes. It can be concluded that if the learning motivation is high, the learning outcomes are good, and vice versa, if the learning motivation is low, the learning outcomes obtained by students will tend to below as well. This is following Sardiman's opinion (Makmur \& Aspia, 2015) that students who are motivated to learn can work continuously for a long time, never stopping before completion.

\section{CONCLUSION}

Based on the findings and discussion of the research results, the following conclusions can be stated: In general, students' learning motivation is in the sufficient category, The score of students' chemistry learning outcomes is in a complete category (reaching the minimum completeness criteria of 65), and There is a significant relationship between learning motivation and student learning outcomes of chemistry.

The suggestions that can be given by researchers are as follows: To improve learning outcomes in chemistry, teachers and parents must motivate as a whole, The motivation given can be in the form of rewards and adulation/praise to students who excel to inspire students, and Further researchers who want to examine the same problem are advised to research different locations and materials and first pay attention to weaknesses such as students who pay less attention when the teacher explains and are slow to complete learning activities to achieve better learning outcomes.

\section{ACKNOWLEDGMENT}

The implementation of the research that I have done is inseparable from the role of several parties for that I would like to express my deepest gratitude, including the following: Dean of the Faculty of Teacher Training and Education, Chair of the Chemistry Education Study Program, Peer Lecturers, principal, chemistry teacher, and students of class XI-MNS state SHS 4 Pematangsiantar.

\section{REFERENCES}

Coakes, S. J. (n.d.). Steed, L \& Ong, C 2010. SPSS: Analysis without Anguish: Version 17 for Windows.

Fatimah, S. (2016). Pengaruh Pembelajaran IPA Menggunakan Project Based Learning (PJBL) Dan Seven Jumps Terhadap 
Keterampilan Proses Dan Karakter Sains Peserta Didik Pada Materi Peristiwa Alam. Prosiding Seminar Nasional Inovasi Pendidikan.

Fitria, R., Marsidin, S., \& Nirwana, H. (2016). Hubungan Persepsi siswa tentang budaya sekolah dan motivasi belajar dengan penyesuaian diri siswa. Konselor, 3(4), 139146.

Gurses, A., Dogar, C., \& Geyik, E. (2015). Teaching of the concept of enthalpy using problem based learning approach. ProcediaSocial and Behavioral Sciences, 197, 23902394.

Makmur, A., \& Aspia, A. (2015). Efektifitas Penggunaan Metode Base Method dalam Meningkatkan Kreatifitas dan Motivasi Belajar Matematika Siswa SMP Negeri 10 Padangsidempuan. EduTech: Jurnal Ilmu Pendidikan Dan Ilmu Sosial, 1(01).

Manurung, H. M. (2019). Implementasi unit kegiatan belajar mandiri (ukbm) terhadap berpikir kratif mahasiswa pada pokok bahasan laju reaksi. Cheds: Journal of Chemistry, Education, and Science, 3(2), 2936.

Maulida, S. R., \& Dhania, D. R. (2012). Hubungan antara Kepercayaan Diri dan Dukungan Orang Tua dengan motivasi berwirausaha pada siswa SMK. Jurnal Psikologi, 11(2), 9.

Muhibbin, S. (2004). Psikologi pendidikan. Bandung: Rosda Karya.

Prins, G. T., Bulte, A. M. W., \& Pilot, A. (2018). Designing context-based teaching materials by transforming authentic scientific modelling practices in chemistry. International Journal of Science Education, 40(10), 1108-1135.
Ratumanan, T. G. (2004). Belajar dan pembelajaran. Surabaya: UNESA university press.

Rumbewas, S. S., Laka, B. M., \& Meokbun, N. (2018). Peran Orang Tua Dalam Miningkatkan Motivasi Belajar Peserta Didik di Sd Negeri Saribi. EduMatSains: Jurnal Pendidikan, Matematika Dan Sains, 2(2), 201-212.

Sari, Y., Sutrisno, S., \& Sugiyanti, S. (2020). Experimentation of Problem Based Learning (PBL) Model on Student Learning Motivation and Achievement on Circle Material. Formatif: Jurnal Ilmiah Pendidikan MIPA, 9(4).

Sitompul, R. S., Astalini, A., \& Alrizal, A. (2018). Deskripsi Motivasi Belajar Fisika Siswa Kelas X Mia Di Sman 9 Kota Jambi. Edufisika: Jurnal Pendidikan Fisika, 3(02), 22-31.

Suryanti, S., \& Wijayanti, L. (2019). Literasi Digital: Kompetensi Mendesak Pendidik Di Era Revolusi Industri 4.0. EduStream: Jurnal Pendidikan Dasar, 2(1), 1-9.

Tarigan, S., \& Manurung, H. (2015). Penerapan Model Pembelajaran Problem Based Learning (PBL) dengan Menggunakan Macromedia Flash Untuk Meningkatkan Berpikir Kreatif dan Hasil Belajar Siswa Pada Pokok Bahasan Kelarutan dan Hasil Kali Kelarutan. TABULARASA, 12(2).

Taufiq, M., Susilo, H., Irawati, M. H., \& Saptasari, M. (2018). Profil Motivasi Belajar Siswa Sma Kelas X Dengan Kelas Xi Ipa Pada Pelajaran Biologi Di Kota Surabaya. Natural Science Education Research, 1(2), 214-222. 